\title{
Eksplorasi efektifitas model spasial untuk menjelaskan hubungan antara penduduk dan infrastruktur terhadap kesejahteraan masyarakat Kota Manado
}

\author{
Winsy Weku \\ Jurusan Matematika, Universitas Sam Ratulangi, Manado \\ Email: winsy_weku@unsrat.ac.id

\begin{tabular}{lll}
\hline Recieved: 11-02-2021 & $\begin{array}{c}\text { Riwayat artikel: } \\
\text { Revised: } 19-02-2021\end{array}$ Accepted: 22-02-2021 \\
\hline
\end{tabular}

\section{Abstract} \\ This study was conducted to determine a family welfare model that is influenced by the \\ population and infrastructure in Manado using spatial regression and spatial weighted \\ regression, to analyze the factors that influence it and to examine the effectiveness of the \\ spatial regression method in analyzing the case. The analysis used is the Spatial Error \\ Model followed by Geographical Weighted Regression. The results of the analysis show \\ that the predictor variables that affect the response variable are population, number of \\ schools and health facilities. The assessment criteria prefer the GWR model to explain \\ family welfare because it has a smaller AIC value than using the SEM model.
}

Keywords: welfare family, SEM, GWR

\begin{abstract}
Abstrak
Penelitian ini dilakukan untuk menentukan model kesejahteraan keluarga yang dipengaruhi oleh jumlah penduduk dan infrastruktur di kota Manado menggunakan regresi spasial dan regresi terboboti spasial, menganalisis faktor-faktor yang mempengaruhinya serta mengkaji efektifitas metode regresi spasial dalam menganalisis kasus tersebut. Analisis yang digunakan yaitu Spatial Error Model (SEM) dilanjutkan dengan Geographicaly Weighted Regression (GWR). Hasil analisis menunjukkan bahwa variabel prediktor yang mempengaruhi variabel respon adalah jumlah penduduk, jumlah sekolah dan sarana kesehatan. Kriteria penilaian lebih memilih Model GWR untuk menjelaskan kesejahteraan keluarga karena memiliki nilai AIC lebih kecil dibandingkan menggunakan model SEM..
\end{abstract}

Kata kunci: Keluarga sejahtera, SEM, GWR

\section{Pendahuluan}

Pembangunan Sumber Daya Manusia (SDM) merupakan hal mutlak bagi setiap negara maju ataupun berkembang. Negara-negara maju, misalnya di Eropa atau Amerika memiliki indikator-indikator untuk mengukur SDM yang berdampak pada Indeks Pembangunan Manusia (IPM) [1][2]. Sementara itu di negara berkembang, misalnya Indonesia telah menentukan indikator-indikator yang telah 
AITI: Jurnal Teknologi Informasi

Volume 17 No. 2 Agustus 2020, 130-142

diuji kesesuaiannya untuk masyarakat Indonesia lewat Badan Pusat Statistika. Adapun kota Manado telah berkembang dengan pesat selama beberapa dekade yang dapat dilihat dari bertambahnya infrastruktur dipusat kota. Pertambahan infrastruktur ini diharapkan dapat menunjang pergerakan sosial dan aktivitas ekonomi. Sehingga dibutuhkan suatu analisis secara mendasar untuk melihat apakah pertumbuhan infrastruktur memiliki pengaruh yang relatif signifikan terhadap tingkat kesejahteraan masyarakat kota Manado khususnya masyarakat pra-sejahtera [3].

Beberapa metode telah digunakan oleh beberapa peneliti untuk mengukur dampak infrastruktur terhadap tingkat kesejahteraan masyarakat tersebut, baik secara non-spasial misalnya ekuilibrium Nash [4], beberapa metode konvensional lainnya [1], [5], [6] ataupun melalui pengukuran secara spasial misalnya adanya kebergantungan spasial antara wilayah sebagai objek amatan [7], atau bisa saja menggunakan Spatial Error Model (SEM) [8] dengan memperhatikan error atau Geographically Weighted Regression (GWR) [9]-[11] karena adanya keragaman pada objek penelitian. Pemodelan secara spasial merupakan pengembangan berdasarkan hukum Tobler geografi pertama yang menyatakan bahwa segala sesuatu saling berhubungan satu dengan yang lainnya, tetapi sesuatu yang dekat mempunyai pengaruh yang lebih dari pada sesuatu yang jauh. Ini berarti adanya pengaruh tempat atau spasial pada data yang dianalisis, sebenarnya telah digunakan oleh beberapa peneliti yang mengembangkan regresi spasial diantaranya Anselin, et al. [12] dan LeSage.

Karena kesejahteraan masyarakat disuatu lokasi dipengaruhi oleh infrastruktur, maka perlu dilakukan suatu kajian terukur dengan memperhatikan masalah spasial maupun non-spasial. Masalah mendasar sebenarnya adalah faktor mana saja yang memberikan pengaruh nyata terhadap kesejahteraan masyarakat dalam hal ini keluarga pra sejahtera, menggunakan metode yang melibatkan ketetanggaan spasial dibandingkan metode yang tidak melibatkan ketetanggaan spasial. Sehingga secara umum dapat dikatakan dalam penelitian ini akan dilakukan eksplorasi untuk melihat model spasial mana yang memberikan pendekatan yang relatif sesuai untuk memodelkan pengaruh tingkat penduduk dan infrastruktur terhadap kesejahteraan masyarakat Kota Manado.

\section{Kajian Pustaka}

Untuk melihat kedekatan hubungan antara wilayah satu dengan wilayah lain pada data spasial dapat digunakan matriks pembobot spasial. Jenis-jenis matriks pembobot spasial antara lain persinggungan tepi (linier contiguity), persinggungan sisi (rook contiguity), persinggungan sudut (bishop contiguity), dan persinggungan sisi-sudut (queen contiguity) atau matriks pembobot jarak [13][7].

Secara mendasar Spatial Autoregresive Model (SAR) merupakan model spasial yang terjadi akibat adanya pengaruh spasial pada variabel dependen. Adapun Spatial Error Model (SEM) merupakan model spasial yang terjadi akibat adanya pengaruh spasial pada error. Apabila data yang diperoleh menghasilkan 
dependensi lag maka data dimodelkan dengan SAR, tetapi apabila data menghasilkan dependensi error maka data dimodelkan dengan SEM. Jika data menghasilkan dependensi lag dan dependensi error maka data dimodelkan dengan Spatial Autoregressive Moving Average (SARMA).

\section{a. Regresi Linier Berganda dengan Metode Kuadrat Terkecil (RKT)}

Persamaan regresi linier berganda dalam bentuk matriks adalah sebagai berikut [12].

$$
\mathrm{Y}=\mathrm{X} \boldsymbol{\beta}+\boldsymbol{\varepsilon}
$$

dimana $\mathrm{Y}$ adalah vektor variabel dependen, $\mathrm{X}$ adalah matriks variabel independen, $\boldsymbol{\beta}$ adalah vektor koefisien parameter regresi, dan $\boldsymbol{\varepsilon}$ adalah vektor error regresi. Adapun rumus penaksir parameter kuadrat terkecil, yaitu sebagai berikut.

$$
\hat{\beta}=\left(\mathrm{X}^{t} \mathrm{X}\right)^{-1} \mathrm{X}^{t} \mathrm{Y}
$$

\section{b. Model Regresi Spasial}

Model umum regresi spasial adalah sebagai berikut [12]

$$
\begin{aligned}
& \mathbf{y}=\rho \mathrm{Wy}+\mathrm{X} \boldsymbol{\beta}+\mathbf{u} \\
& \mathbf{u}=\lambda \mathrm{Wu}+\boldsymbol{\varepsilon} \\
& \mathbf{y}=\rho \mathrm{W} \mathbf{y}+\mathrm{X} \boldsymbol{\beta}+\lambda \mathrm{Wu}+\boldsymbol{\varepsilon} \\
& \boldsymbol{\varepsilon} \sim \mathrm{N}\left(0, \mathrm{I}^{2}\right)
\end{aligned}
$$

dimana $\mathbf{W}$ adalah matriks pembobot spasial, $\mathbf{u}$ dan $\boldsymbol{\varepsilon}$ adalah vektor error, $\rho$ adalah parameter koefisien spasial lag variabel dependen, $\lambda$ adalah parameter koefisien spasial lag error, I adalah matriks identitas, $n$ adalah banyaknya amatan, serta $k$ adalah banyaknya variabel-variabel independen.

\section{Spatial Error Model}

Berdasarkan persamaan (2), jika $\rho=0$ dan $\lambda \neq 0$ maka model regresi spasial akan menjadi Spatial Error Model (SEM) dapat dituliskan sebagai berikut [12].

$$
\mathbf{y}=\mathbf{X} \boldsymbol{\beta}+(\mathbf{I}-\lambda \mathrm{W})^{-1} \boldsymbol{\varepsilon}
$$

Adapun bentuk penaskir parameter dari model regresi SEM, yaitu sebagai berikut.

$$
\hat{\beta}=\left[(\mathrm{X}-\lambda \mathrm{WX})^{\mathrm{t}}(\mathrm{X}-\lambda \mathrm{WX})\right]^{-1}(\mathrm{X}-\lambda \mathrm{WX})^{\mathrm{t}}(\mathrm{I}-\lambda \mathrm{W}) \mathrm{y}
$$

dimana

$\alpha$ : vektor parameter konstan, berukuran $\mathrm{n} \times 1$

$\boldsymbol{\beta}$ : vektor parameter regresi, berukuran $\mathrm{k} \times 1$

$\theta$ : vektor parameter lag spasial variabel prediktor berukuran $\mathrm{k} \times 1$

\section{Efek Spasial}

Dependensi spasial terjadi akibat adanya dependensi dalam data wilayah. Spatial dependence muncul berdasarkan hukum Tobler I (1979). Uji untuk mengetahui spatial dependence di dalam suatu model adalah statistik Moran's I dan Langrange Multiplier (LM) [12]. Moran's I adalah sebuah tes statistik lokal untuk melihat nilai autokorelasi spasial, yang digunakan untuk mengidentifikasi suatu 
lokasi dari pengelompokan spasial atau autokorelasi spasial. Rumus Moran's I dalam bentuk normalitas, yaitu: $I=\frac{e^{\prime} W e}{e^{\prime} e}$ dengan $e_{i}=y_{i}-\frac{1}{n} \sum_{i=1}^{n} y_{i}$ adalah suatu vektor deviasi untuk rata-rata sampel dan $\mathrm{W}=\left[\mathrm{w}_{\mathrm{ij}}\right]$ adalah matriks bobot spasial. Nilai ekspektasi dari Moran's I adalah: $E(I)=I_{0}=-\frac{1}{n-1}$. Jika I $>I_{0}$, maka nilai autokorelasi bernilai positif, hal ini berarti bahwa pola data membentuk kelompok (cluster), $\mathrm{I}=\mathrm{I}_{0}$ artinya tidak terdapat autokorelasi spasial, dan $\mathrm{I}<\mathrm{I} 0$ artinya nilai autokorelasi bernilai negatif, hal ini berarti pola data menyebar.

Selanjutnya uji LM digunakan untuk menentukan kehadiran efek spasial atau tidak didalam model. Bentuk tes LM pada SEM, yaitu: $L M=$ $\left(\frac{1}{T}\right)\left(\frac{e^{\prime} W y}{\sigma^{2}}\right)^{2} \sim \chi^{2}(1) ; \mathrm{T}=\operatorname{trace}\left[\left(\mathrm{W}^{\prime}+\mathrm{W}\right) . * \mathrm{~W}\right], \sigma^{2}=\frac{e^{\prime} e}{n}$, dimana $*$ melambangkan operasi perkalian titik pada elemen matriks. Hipotesis yang digunakan pada Uji Lagrange Multiplier (LM) untuk SEM, $\mathrm{H}_{0}: \rho=0$ dan $\mathrm{H}_{1}: \rho \neq 0$. Dalam mengambil keputusan, tolak $\mathrm{H}_{0}$ jika $\mathrm{LM}>\chi 2$ atau $\mathrm{p}$-value $<\alpha$.

\section{c. Model Geographically Weighted Regression (GWR)}

Metode GWR adalah suatu teknik yang membawa kerangka dari model regresi sederhana menjadi model regresi yang terboboti [14]. Model ini merupakan model regresi linier lokal (locally linier regression) yang menghasilkan penaksir parameter model yang bersifat lokal untuk setiap tit ik atau lokasi dimana data tersebut dikumpulkan. Pada model GWR, variabel dependen diprediksi dengan variabel independen yang masing-masing nilai parameter regresinya bergantung pada lokasi dimana data tersebut diamati. Model GWR selanjutnya dapat ditulis sebagai berikut :

$$
y_{i}=\beta_{0}\left(u_{i}, v_{i}\right)+\sum_{k=1}^{p} \beta_{k}\left(u_{i}, v_{i}\right) x_{i k}+\varepsilon_{i}
$$

dengan

$\mathrm{y}_{\mathrm{i}}$ : pengamatan pada lokasi ke-i $(\mathrm{i}=1,2, \ldots, \mathrm{n})$

$\mathrm{x}_{\mathrm{ik}}$ : nilai observasi variabel independen $\mathrm{k}$ padapengamatan ke-i

$\left(\mathrm{u}_{i}, \mathrm{~V}_{\mathrm{i}}\right)$ : koordinat (longitude, latitude) dari titik ke-i pada suatu lokasi geografis.

$\mathrm{b}_{\mathrm{k}}\left(\mathrm{u}_{\mathrm{i}}, \mathrm{V}_{\mathrm{i}}\right)$ : parameter regresi pada titik ke-i

$\varepsilon_{i}$ : error yang diasumsikan identik, independen dan berdistribusi Normal dengan mean nol dan variansi konstan.

Jika nilai parameter regresi konstan pada tiap-tiap wilayah geografis, maka model GWR adalah model global. Artinya tiap-tiap wilayah geografis mempunyai model yang sama. Hal ini merupakan kasus spesial dari GWR. Pada model GWR diasumsikan bahwa data observasi yang dekat dengan titik ke-i mempunyai pengaruh yang besar pada estimasi dari $b_{k}\left(u_{i}, V_{i}\right)$ daripada data yang berada jauh dari titik ke-i.

Peran pembobot pada model GWR sangat penting karena nilai pembobot ini mewakili letak data observasi satu dengan lainnya. Oleh karena itu, sangat dibutuhkan ketepatan cara pembobotan. Skema pembobotan pada GWR dapat menggunakan beberapa metode yang berbeda, salah satu metode pembobotan yang 
biasa digunakan adalah kernel Gaussian dan fungsi pembobotan bisquare. Fungsi Gaussian untuk menghitung titik ke- $n$ yang terdekat adalah [15] $W_{i j}=$ $\exp \left[-\frac{\left(d_{i j} / b\right)^{2}}{2}\right]$; dimana $\mathrm{j}$ : salah satu titik ke-n yang terdekat dari titik ke- $\mathrm{i}, \mathrm{b}$ : jarak titik ke-n yang terdekat, $\mathrm{d}_{\mathrm{ij}}$ : merupakan jarak Euclidean.

Kriteria untuk penentuan nilai $\mathrm{n}$ yang tepat dapat diperoleh dengan pendekatan least square yaitu dengan menggunakan kriteria cross-validation $\mathrm{CV}=$ $\sum_{i=1}^{n}\left[y_{i}-\hat{y}_{i^{*}(b)}\right]^{2}$ dengan $i^{*} \neq \mathrm{i}$ dan $\hat{y}_{i^{*}(b)}$ adalah nilai dugaan untuk $\mathrm{y}_{\mathrm{i}}$ dengan pengamatan pada titik ke-i diabaikan dalam proses penaksiran.

\section{Metode Penelitian}

\section{a. Data Penelitian}

Wilayah amatan merupakan wilayah administrasi desa sebanyak 88 desa di kotamadya Manado. Variabel yang diteliti disetiap desa dipilih berdasarkan pertimbangan ketersediaan data yang ada pada BPS Kota di Kota Manado, yakni

$\mathrm{y}=$ Keluarga pra sejahtera (KPS) di setiap desa.

$\mathrm{X} 1=$ Jumlah penduduk di setiap desa.

$\mathrm{X} 2$ = Jumlah RT yang memiliki rumah permanen di setiap desa.

$\mathrm{X} 3=$ Jumlah rumah tangga di setiap desa.

X4 = Jumlah RT yang memiliki akses listrik di setiap desa.

X5 = Jumlah Pasangan Usia Subur (memiliki akses kesehatan) di tiap desa.

X6 = Jumlah usaha (kegiatan perekonomian) di setiap desa.

$\mathrm{X} 7=$ Jumlah infrastruktur pendidikan di setiap desa.

$\mathrm{X} 8=$ Jumlah infrastruktur rumah ibadah di setiap desa.

X9 = Jumlah infrastruktur kesehatan di setiap desa.

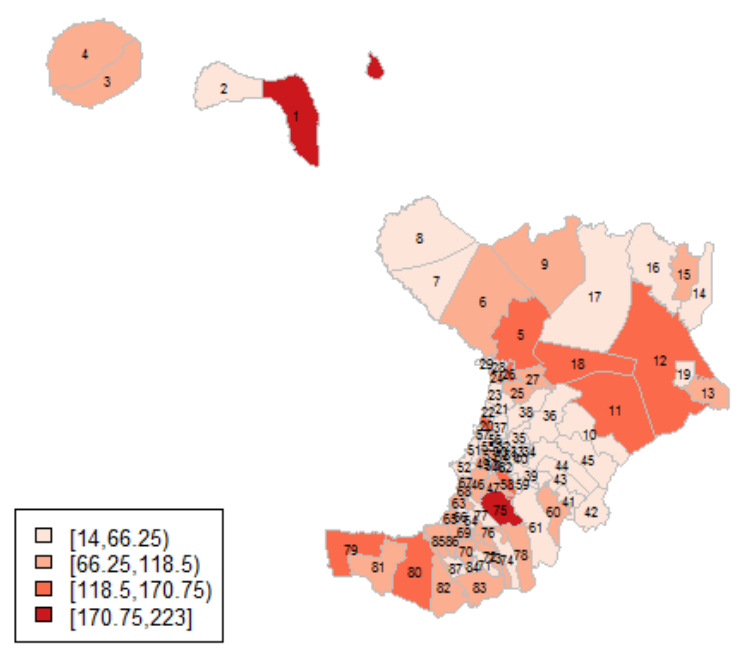

Gambar 1. Wilayah Amatan kota Manado dengan variabel keluarga pra sejahtera 
AITI: Jurnal Teknologi Informasi

Volume 17 No. 2 Agustus 2020, 130-142

Berdasarkan jumlahnya, keluarga pra sejahtera (KPS) dapat dikelompokan atau dipetakan menjadi 4 interval wilayah. Kelas interval $(14-66,25)$ menunjukkan jumlah KPS terendah berada disekitar pusat kota yang memiliki infrastruktur dan pergerakan perekonomian yang cukup tinggi. Sedangkan kelas interval (170,75223) merupakan kelas dimana jumlah KPS tertinggi berada dibeberapa desa/kelurahan terluar yang memiliki infrastruktur perekonomian yang rendah. Pemetaan tersebut dapat dilihat pada Gambar 1 di atas.

b. Langkah-langkah Penelitian

Interpretasi kinerja model Regresi Kuadrat Terkecil didasarkan pada penilaian multi-collinearity, probabilitas kuat, kriteria informasi $\mathrm{R}^{2}$ dan Akaike Information Criteria (AIC) [16]. Kriteria informasi Akaike (AIC) kemudian digunakan untuk menentukan model RKT terbaik.

Langkah selanjutnya adalah mengeksplorasi model GWR yang bisa menjelaskan variasi jumlah keluarga pra sejahtera berdasarkan hubungan antara penduduk dan infrastruktur. Autokorelasi spasial (Global Moran's I) digunakan untuk menilai apakah faktor lingkungan menunjukkan pola spasial acak [7], dan bila model yang memadai akan memiliki distribusi acak residual [9]. Dalam kondisi non-stasioneritas, regresi geografis terboboti (GWR) dieksplorasi untuk berpotensi memperbaiki hasil pemodelan RKT. Variabel penjelas yang sama yang digunakan dalam pemodelan OLS digunakan untuk menjalankan GWR daripada memulai dengan kumpulan parameter global yang lengkap, sehingga tidak menimbulkan "perbaikan" yang tidak dapat dikaitkan dengan pendekatan pemodelan yang diterapkan. Dengan kata lain, jika pemodelan GWR tidak diterapkan pada variabel yang sama dengan pemodelan RKT, namun menghasilkan hasil yang lebih baik, tidak akan tahu apakah perbaikan tersebut disebabkan oleh pendekatan pemodelan atau data amatan yang digunakan untuk membangun setiap model.

Setelah faktor amatan utama diidentifikasi selama pemodelan RKT, dilanjutkan untuk mengeksplorasi variabilitas spasial koefisien regresi lokal untuk menentukan apakah proses yang mendasari menunjukkan heterogenitas spasial [17]. Model lokal GWR diterapkan untuk menganalisis bagaimana hubungan antara jumlah penduduk dan faktor infrastruktur berubah dari satu desa ke desa lainnya. Tidak seperti pemodelan regresi RKT konvensional, yang menghasilkan persamaan regresi tunggal untuk merangkum hubungan global di antara variabel independen dan dependen, GWR mendeteksi variasi spasial dalam hubungan dalam model dan menghasilkan informasi yang berguna untuk mengeksplorasi dan menafsirkan spasial non-stasioneritas.

Kernel spasial digunakan untuk memberikan pembobotan geografis untuk jendela lokal yang berpusat pada node grid yang digunakan pada model kami. Ada dua kemungkinan kategori kernel spasial: fixed/adaptive dan bandwidth, yang merupakan koefisien kunci yang mengendalikan ukuran kernel [18]. Kernel ini cenderung Gaussian yang menyiratkan lokasi titik terjauh diboboti lebih rendah daripada yang dekat. Ada tiga potensi pendekatan bandwidth: Kriteria informasi Akaike (AIC), validasi silang (CV) dan parameter bandwidth. Pemodelan dan pengolahan data dilakukan dengan urutan sebagai berikut: 
a. Melakukan eksplorasi peta tematik untuk mengetahui pola penyebaran dan dependensi pada masing-masing variabel serta scatterplot untuk mengetahui pola hubungan variabel $\mathrm{X}$ dan $\mathrm{Y}$.

b. Melakukan pemodelan regresi dengan metode RKT yang meliputi estimasi parameter dan estimasi signifikansi model.

c. Uji dependensi atau korelasi.

d. Identifikasi keberadaan efek spasial dengan uji Lagrange Multiplier (LM) dan Moran's I Statistics.

e. Proses pemodelan, yaitu data dimodelkan dengan Spatial Autoregresive Model (SAR), Spatial Error Model (SEM), atau Spatial Autoregresive Moving Average (SARMA).

f. Pemilihan Bandwidth dan fungsi kernel.

g. Pemodelan Regresi Geografi Terboboti.

\section{Hasil dan Pembahasan}

\section{a. Graf tetangga dan Plot Moran}

Hal mendasar yang dilakukan adalah mengetahui terjadinya autokorelasi spasial ataukah tidak menggunakan indeks Moran. Adapun matriks terboboti yang digunakan adalah matriks ketetanggaan queen. Selanjutnya, disajikan graph contiguity yaitu gambar ketetanggaan desa satu dengan yang lain di Kota Manado sebagai dasar untuk pembuatan matrik spasial, dan diagram Moran's yaitu diagram untuk melihat pola pengelompokan data beserta nilai-nilai Moran's I. Gambar ketanggaan antar desa menggunaan ketetanggaan queen dan plot diagram Moran ditunjukkan seperti Gambar 2.
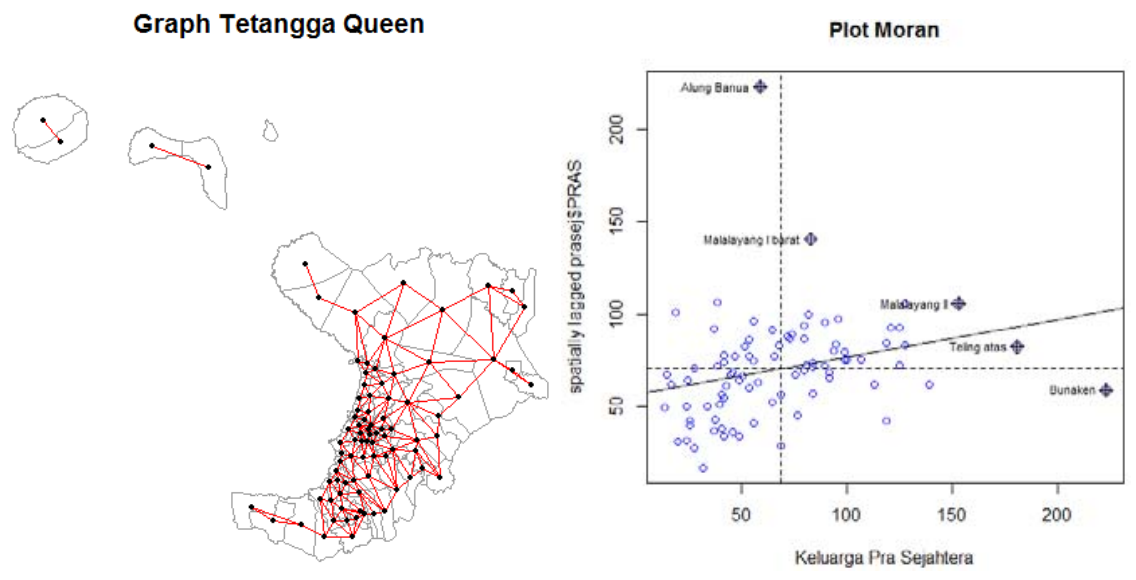

Gambar 2. Graf ketetanggaan queen dan scatterplot moran

Beberapa variabel yang lain juga dilakukan perhitungan koefisien korelasi Moran. Secara umum dirangkum pada Tabel 2 ditunjukkan bahwa semua nilai Moran's I bernilai lebih besar dari $\mathrm{I}_{0}=-0,01$ (nilai ekspektasi Moran), yang artinya semua data pada variabel baik bebas Y (jumlah masyarakat pra sejahtera) maupun terikat 
AITI: Jurnal Teknologi Informasi

Volume 17 No. 2 Agustus 2020, 130-142

(X1 sampai X9) berautokorelasi positif. Atau dengan kata lain adanya indikasi pengelompokan (klastering) dari nilai yang sama untuk setiap variabel amatan.

Tabel 1. Nilai Moran untuk setiap variabel terhadap lag spasial

\begin{tabular}{cl}
\hline Variabel & Moran's I \\
\hline Y & 0.202091 \\
X1 & 0.435783 \\
X2 & 0.272363 \\
X3 & 0.0713303 \\
X4 & 0.314489 \\
X5 & 0.313856 \\
X6 & 0.252905 \\
X7 & 0.369305 \\
X8 & 0.185815 \\
X9 & 0.0972981 \\
\hline
\end{tabular}

b. Uji Dependensi Spasial

Berikutnya pada Tabel 2 diperlihatkan hasil uji dependensi spasial sebagai berikut:

Tabel 2. Pengujian kebergantungan spasial

\begin{tabular}{lcl}
\hline \multicolumn{1}{c}{ Uji Dependensi Spasial } & Nilai & \multicolumn{1}{c}{ p-value } \\
\hline Moran's I (error) & 7.4466 & 0.0000000 \\
Lagrange Multiplier (eror) & 43.471 & $4.303 \mathrm{e}-11$ \\
Robust LM (error) & 38.962 & $4.322 \mathrm{e}-10$ \\
Lagrange Multiplier (lag) & 13.486 & 0.0002403 \\
Robust LM (lag) & 8.9774 & 0.002733 \\
Lagrange Multiplier (SARMA) & 52.4483 & 0.0000000 \\
\hline
\end{tabular}

Berdasarkan Tabel 3, diketahui bahwa nilai probabilitas dari Moran's I sebesar 0.0000 lebih kecil dari $\alpha$. Artinya ada dependensi spasial dalam eror regresi. Begitu pula LM (lag) sebesar 0.0002403 lebih kecil dari $\alpha$ artinya terdapat dependensi error sehingga perlu dilanjutkan ke pembuatan Spatial Error Model (SEM).

Berdasarkan uji LM, telah diketahui bahwa pada kasus keluarga pra sejahtera di kota Manado terdapat pengaruh spasial dalam data. Hal ini mengidentifikasikan bahwa pemodelan kurang akurat dengan menggunakan metode RKT karena pada RKT mengabaikan unsur spasial dalam data. Maka pemodelan akan diselesaikan dengan menggunakan regresi spasial.

Selanjutnya disajikan hasil estimasi regresi pada RKT dan SEM pada Tabel 3.

Tabel 3. Perbandingan koefisien antara RKT dan SEM

\begin{tabular}{lll}
\hline \multicolumn{1}{c}{ Variabel } & \multicolumn{1}{c}{ RKT } & \multicolumn{1}{c}{ SEM } \\
\hline Konstanta & 11.5564 & 1.1657 \\
X1 = Jumlah Penduduk & 0.00637516 & 0.0101771 \\
X2 = Rumah permanen & -0.00110223 & -0.00747822 \\
\hline
\end{tabular}




\begin{tabular}{lll}
\hline \multicolumn{1}{c}{ Variabel } & \multicolumn{1}{c}{ RKT } & \multicolumn{1}{c}{ SEM } \\
\hline X3 = Rumah Tangga & -0.00172123 & -0.00581785 \\
X4 = Akses Listrik & 0.00039982 & 0.00306299 \\
X5 = Sarana Kesehatan & 2.46851 & 2.7472728 \\
X6 = Usaha Ekonomi & -0.00468115 & -0.0490344 \\
X7 = Banyaknya Sekolah & 1.67396 & 1.38141 \\
X8 = Sarana Ibadah & 0.241186 & 0.316257 \\
X9 = Pasangan Usia Subur & 0.0034009 & 0.0033321 \\
$\mathrm{R}^{2}$ & 0.458372 & 0.682267 \\
lambda & & 0.605452 \\
Jmlh kuadrat eror & 885.983 & 459.999 \\
Taraf signifikansi $(\alpha)=0,05$ & & \\
\hline
\end{tabular}

Berdasarkan hasil dari SEM tersebut menunjukkan adanya kebergantungan spasial pada error. Koefisien lambda bertanda positif dan signifikan pada tingkat $5 \%$, artinya ada keterkaitan keluarga pra sejahtera pada suatu desa dengan desa lainnya yang berdekatan. Sehingga dapat disimpulkan bahwa lambda berperan penting pada pemodelan SEM. Selain itu sembilan variabel berperan penting pada SEM dengan taraf signifikansi 5\%. Artinya, tingkat keluarga pra sejahtera di suatu desa dipengaruhi oleh nilai dari sembilan variabel desa tersebut serta residual spasial dari desa lain yang berdekatan dan memiliki karakteristik sama.

Model SEM yang terbentuk adalah sebagai berikut

$$
\begin{aligned}
& \mathrm{y}=1.1657+0.0101771 \mathrm{X} 1-0.00747822 \mathrm{X} 2-0.00581785 \mathrm{X} 3+0.00306299 \\
& \mathrm{X} 4+0.2 .7472728 \times 5-0.0490344 \mathrm{X} 6+1.38141 \mathrm{X} 7+0.316257 \mathrm{X} 8+ \\
& 0.0033321 \mathrm{X} 9+\mathrm{u}_{\mathrm{i}} \\
& u_{i}=0.605452+\sum_{\mathrm{i} \neq \mathrm{j}, \mathrm{j}=1}^{\mathrm{n}} \mathrm{w}_{\mathrm{ij}} \mathrm{u}_{\mathrm{j}}+\varepsilon_{\mathrm{i}}
\end{aligned}
$$

c. Pengujian dari Asumsi Model SEM

Kenormalan residual dapat diuji secara formal dengan menggunakan Uji Kolmogorov-Smirnov (KS), dengan hipotesis yang diajukan sebagai berikut.

$\mathrm{H}_{0}$ : residual menyebar normal

$\mathrm{H}_{1}$ : residual tidak menyebar normal

Nilai KS yang diperoleh sebesar 0,110 lebih kecil dari nilai KS tabel $(0,23)$ dan nilai $\mathrm{p}$-value lebih besar dari $\alpha=5 \%$ sehingga $\mathrm{H}_{0}$ diterima, artinya asumsi kenormalan residual terpenuhi.

Asumsi Residual Autokorelasi Spasial menggunakan Uji Durbin Watson dengan hipotesis yang diajukan sebagai berikut.

$\mathrm{H}_{0}: \rho=0$ (Tidak ada autokorelasi antar lokasi)

$\mathrm{H}_{1}: \rho \neq 0$ (Ada autokorelasi antar lokasi)

Nilai $p$-value pada pengujian Durbin-Watson ini sebesar 0,003 yang lebih kecil dari 0,10 . Ini menunjukkan bahwa pada taraf signifikansi $\alpha=5 \% \mathrm{H}_{0}$ ditolak, artinya terdapat autokorelasi spasial pada residual SEM. 


\section{d. Pemodelan GWR}

Faktor-faktor yang mempengaruhi kesejahteraan masyarakat antara lain jumlah penduduk, sekolah dan sarana kesehatan. Sebelum menggunakan GWR untuk analisis data, terlebih dahulu menggunakan model regresi untuk menganalisis data. Hasil persamaan regresi diasumsikan sama dan diberlakukan untuk semua wilayah pada pemukiman masayarakat. Setelah dilakukan pengujian secara parsial, diketahui bahwa ternyata terdapat tiga variabel yang memiliki pengaruh terhadap keluarga pra sejahtera, yakni jumlah penduduk (X1), sarana kesehatan (X5) dan sarana persekolahan (X7). Secara umum, model regresi antara kesejahteraan masyarakat dan faktor-faktor yang mempengaruhinya adalah:

$$
\hat{y}=12.844922+0.006988 X_{1}+1.639069 X_{5}+2.170759 X_{7}
$$

Pada model GWR yang dibangun pada persamaan (6) terdapat tiga variabel yakni jumlah penduduk, banyaknya infrastruktur pendidikan dan banyaknya infrastruktur kesehatan ditiap desa yang berpengaruh terhadap masyarakat pra sejahtera. Model regresi yang layak digunakan dapat dilihat dari nilai $\mathrm{R}^{2}$. Nilai $\mathrm{R}^{2}$ dikalikan $100 \%$ menunjukkan persentase keragaman di dalam variabel $\mathrm{Y}$ yang dapat diberikan oleh model regresi yang didapatkan. Semakin besar nilai $\mathrm{R}^{2}$, semakin baik model regresi yang diperoleh.

Berdasarkan model regresi spasial dari persamaan (6), maka dibangunlah model GWR yang dalam penelitian ini dapat dituliskan sebagai berikut:

$$
K P S=\beta_{i 0}+\beta_{i 1} X_{i 1}+\beta_{i 5} X_{i 5}+\beta_{i 7} X_{i 7}+\varepsilon_{i}
$$

Karena metode GWR merupakan model lokal, dimana setiap lokasi desa memiliki model yang berbeda dengan desa lainnya, maka akan terdapat 88 model GWR yang dihasilkan. Hasil estimasi koefisien GWR yang bervariasi untuk masing-masing variabel pada setiap desa disajikan secara ringkas pada Tabel 4.

Tabel 4. Ringkasan estimiasi koefisien GWR pada setiap desa.

\begin{tabular}{lllrrrr}
\hline & Min. & \multicolumn{1}{l}{ 1st Qu. } & \multicolumn{1}{l}{ Median } & \multicolumn{1}{l}{ 3rd Qu. } & \multicolumn{1}{c}{ Max. } & \multicolumn{1}{c}{ Global } \\
\hline Konstanta & -45.1107 & -0.60636 & 7.480023 & 19.65486 & 52.8352 & 12.8449 \\
X1 & -0.01207 & 0.006764 & 0.010555 & 0.013307 & 0.07552 & 0.007 \\
X7 & -3.23315 & -0.38461 & 0.249748 & 1.012528 & 28.004 & 1.6391 \\
X9 & -9.43025 & -1.20623 & 0.95106 & 2.049429 & 18.22317 & 2.1708 \\
\hline
\end{tabular}

Hasil ringkasan estimasi koefisien GWR pada Tabel 5, dapat ditampilkan dalam bentuk peta seperti pada Gambar 3 berikut. Perhatikan bahwa warna setiap desa berbeda satu dengan lainnya, hal ini diakibatkan model GWR yang berbeda-beda. 


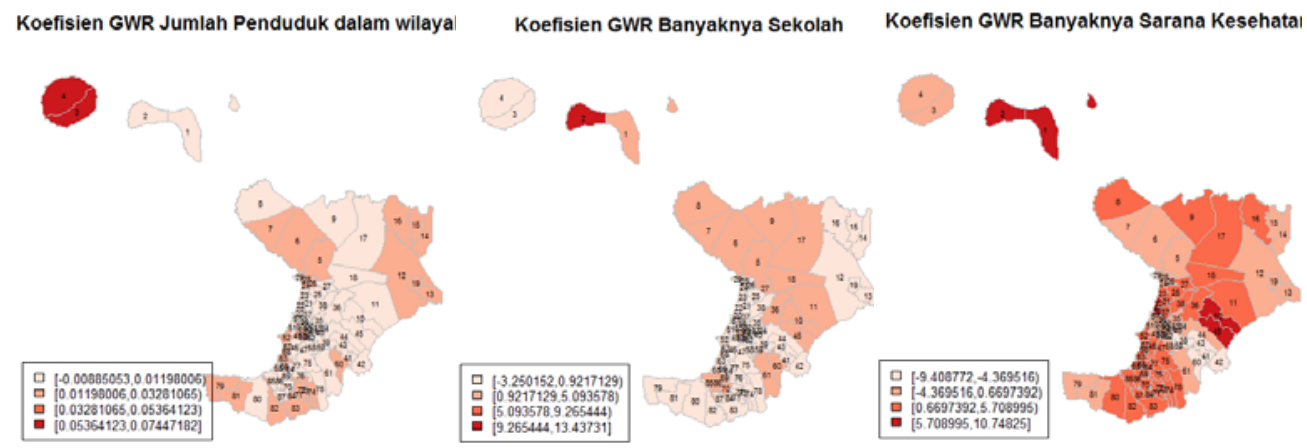

Gambar 3. Peta Koefisien GWR untuk tiga variabel yang mempengaruhi banyaknya keluarga prasejahtera.

Berdasarkan hubungan antara keluarga pra sejahtera dengan ketujuh variabel, dapat diartikan bahwa persamaan dan perbedaan karakteristik pada tiap desa/kelurahan yang berdekatan dapat menimbulkan peningkatan atau penurunan keluarga pra sejahtera pada setiap desa di kota Manado.

Selain itu, Gambar 3 dapat dijelaskan bahwa jumlah penduduk didesa 3 dan 4 (interval kelas 3 di Gambar 1) memberikan kotribusi yang tinggi bagi keluarga pra sejahtera (interval kelas 4 di Gambar 3). Sementara koefisien infrastruktur sekolah memiliki kontribusi yang kecil bagi keluarga prasejahtera (interval kelas 1), demikian halnya koefisien infrastruktur kesehatan.

e. Perbandingan Prediksi Model Regresi RKT, Model SEM dan Model GWR

Kriteria kebaikan sesuai model yang digunakan adalah dengan membandingkan nilai AIC dari ketiga model tersebut.

Tabel 5. Perbandingan Nilai AIC untuk model RKT, SEM dan GWR

\begin{tabular}{ll}
\hline Model & Nilai AIC \\
\hline RKT & 848.715 \\
SEM & 814.5576 \\
GWR & 742.6084 \\
\hline
\end{tabular}

Tabel 5 menunjukkan bahwa model dengan nilai AIC minimal yaitu model GWR yang artinya model GWR sebagai model lokal lebih sesuai untuk menjelaskan keluarga pra sejahtera dibandingkan model SEM. Sehingga model GWR lebih tepat digunakan untuk menganalisis data keluarga pra sejahtera di Kota Manado dibandingkan dengan model regresi dengan menggunakan metode SEM. Akan tetapi secara global model SEM masih lebih cocok digunakan jika dibandingkan model RKT tanpa memperhatikan bobot spasial.

Setiap model yang dihasilkan berdasarkan variabel-variabel amatan dapat digunakan untuk melakukan prediksi terhadap desa yang lain untuk variabel prediktor. Ketiga model baik RKT, SEM maupun GWR memberikan hasil yang hampir menyerupai satu dengan lainnya. Batas bawah kelas untuk GWR lebih kecil dari batas bawah model SEM dan RKT, sedangkan batas atas GWR berada diantara batas atas model RKT (atau OLS) dan model SEM. 
AITI: Jurnal Teknologi Informasi

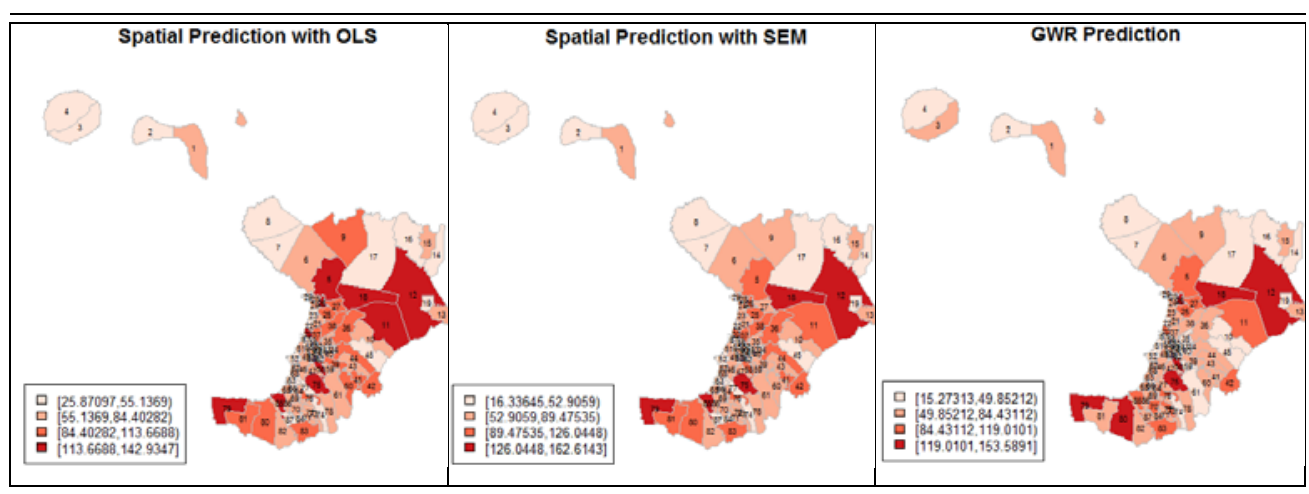

Gambar 4. Hasil prediksi untuk ketiga model RKT, SEM dan GWR

Berdasarkan Gambar 4, distribusi prediksi non-spasial (RKT) untuk kasus keluarga prasejahtera dengan sembilan variabel bergantung memberikan hasil yang hampir sama dengan prediksi spasial model lokal (GWR) yang menggunakan hanya tiga variabel bergantung. Hal ini memberikan indikasi bahwa prediktor ketiga model berperilaku hampir mirip, dimana model lokal GWR dengan variabel lebih sedikit dapat menjelaskan lebih sesuai terhadap keluarga pra sejahtera.

\section{Simpulan}

Dari hasil dan pembahasan yang dipaparkan diatas, dapat dijelaskan sebagai beberapa hal sebagai berikut. Jumlah penduduk, banyaknya sarana sekolah dan sarana kesehatan berpengaruh siginifikan bagi kesejahteraan masyarakat (khususnya keluarga pra sejahtera) di Manado. Model SEM adalah model regresi spasial yang digunakan karena pada kasus keluarga pra sejahtera di kota Manado hanya bergantung pada error saja, dimana model SEM di setiap wilayah desa adalah berbeda satu dengan yang lain karena memliki ketergantungan spasial yang berbeda-beda. Model GWR yang bersifat lokal memperbaiki model SEM dan ditunjukkan lewat nilai AIC yang paling kecil. Prediksi penyebaran kesejahteraan keluarga dapat ditunjukkan lewat map untuk ketiga model (RKT, SEM dan GWR).

\section{Daftar Pustaka}

[1] L. Fransen dan G. Bufalo, "Boosting Investment in Social Infrastructure in Europe", Report of the High-Level Task Force on Investing in Social Infrastructure in Europe, 2018.

[2] S. J. Redding et al., "Quantitative Spatial Economics", 2016.

[3] Badan Pusat Statistik, "Kota Manado dalam Angka 2018”. BPS Kota Manado, 2018.

[4] T. Knaap dan J. Oosterhaven, "Measuring the welfare effects of infrastructure: A simple spatial equilibrium evaluation of Dutch railway proposals Research in Transportation Economics Measuring the welfare effects of infrastructure: A simple spatial equilibrium evaluation of Dutch ra," Res. Transp. Econ., vol. 31, no. 1, hal. 19-28, 2018.

[5] B. G. Johansen dan W. Hansen, "Predicting market allocations, user benefits and wider economic impacts of large infrastructure investments for freight transportation," in Transportation Research Procedia, 2016, vol. 16, no. 
2352, hal. 146-157.

[6] L. Wang, X. Xue, Z. Zhao, dan Z. Wang, "The Impacts of Transportation Infrastructure on Sustainable Development: Emerging Trends and Challenges," Int. J. Environ. Res. Public Health, 2018.

[7] W. Weku, H. Pramoedyo, A. Widodo, dan R. Fitriani, "Non-monoton Nonparametric Variogram to Model the Land Price of Manado City with Hole Effect Periodicity Structure," in IOP Conf. Series: Materials Science and Engineering, 2019, hal. 1-10.

[8] M. Davern et al., "Using spatial measures to test a conceptual model of social infrastructure that supports health and wellbeing," Cities Heal., vol. 8834, hal. $1-16,2018$.

[9] K. Lewandowska-gwarda, "Geographically Weighted Regression in the Analysis of Unemployment in Poland," Int. J. Geo-Information, 2018.

[10] J. Kim dan S. Nicholls, "Using Geographically Weighted Regression to Explore the Equity of Public Open Space Distributions," J. Leis. Res., vol. 48, no. 2, hal. 105-133, 2016.

[11] B. Kim dan T. Kim, "A Study on Estimation of Land Value Using Spatial Statistics: Focusing on Real Transaction Land Prices in Korea," Sustainability, 2016.

[12] L. Anselin, "Spatial Econometrics: Methods and Models". Kluwer Academic Publishers Group, 1988.

[13] R. Webster dan M. A. Oliver, Geostatistics for Environmental Scientists., vol. 1. John Wiley \& Sons Ltd, 2007.

[14] A. S. Fotheringham, C. Brunsdon, dan M. Charlton, "Geographically Weighted Regression". West Sussex: JOHN WILEY \& SONS, LTD, 2002.

[15] J. A. Yacim dan D. G. B. Boshoff, “A Comparison of Bandwidth and Kernel Function Selection in Geographically Weighted Regression for House Valuation," Int. J. Technol., vol. 10, no. 1, hal. 58-68, 2019.

[16] L. Guo, Z. Ma, dan L. Zhang, "Comparison of bandwidth selection in application of geographically weighted regression: a case study," Can. J. For. Res., vol. 38, no. 9, hal. 2526-2534, 2008.

[17] A. S. Fotheringham, "The Problem of Spatial Autocorrelation' and Local Spatial Statistics," Geogr. Anal., vol. 41, hal. 398-403, 2009.

[18] P. E. Bidanset dan J. R. Lombard, "Evaluating Spatial Model Accuracy in Mass Real Estate Appraisal A Comparison of Geographically Weighted Regression and the Spatial Lag Model", Source: Cityscape, vol. 16, no. 3, hal. 169-182, 2014. 